\title{
A Simple Isocratic High-perfomance Liquid Chromatography Method for the Simultaneous Determination of Shikonin Derivatives in Some Echium Species Growing Wild in Turkey
}

\author{
Türkiye'de Yabani Yetişen Bazı Echium Türlerindeki Şikonin Türevlerinin \\ Basit İzokratik HPLC Yöntemiyle Eşzamanlı Olarak Belirlenmesi
}

\author{
(D) Nuraniye ERUYGUR \\ Cumhuriyet University, Faculty of Pharmacy, Department of Pharmacognosy, Sivas; \\ Selcuk University, Faculty of Pharmacy, Department of Pharmacognosy, Konya, Turkey
}

\begin{abstract}
Objectives: Dried roots of Echium species are used in Turkey for the treatment of wounds, inflammation, and depression. In this study, an reversedphase-liquid chromatographic method with isocratic elution was developed to determine shikonin derivatives in Echium species.

Materials and Methods: The chromatographic separation and quantification was performed on a C18 column (ACE, $150 \mathrm{~mm} \times 4.6 \mathrm{~mm}, 5 \mu \mathrm{m}$ ), with a mobile phase of acetonitrile and $0.1 \mathrm{M}$ acetic acid $(70: 30, \mathrm{v} / \mathrm{v}$ ) at a flow rate of $1 \mathrm{~mL} / \mathrm{min}$, and ultraviolet detection at $520 \mathrm{~nm}$.

Results: Linear behavior was observed over the investigated concentration range $(2-500 \mathrm{ppm})$ for all analytes, with a correlation coefficient of $>0.998$. The proposed method was found to be specific and precise for the quantification of shikonin derivatives in Echium species.

Conclusion: The highest content of shikonin derivatives was observed in E. italicum L. compared with the other species studied herein, advocating the use of E. italicum L. roots as an alternate source for shikonin derivatives.
\end{abstract}

Key words: Echium sp., shikonin derivatives, HPLC

\section{ÖZ}

Amaç: Türkiye'de Echium türlerinin kurutulmuş kökleri yara, enflamasyon ve depresyon tedavisinde kullanılmaktadır. Bu çalıșmada, Echium türlerinde bulunan şikonin türevlerinin içeriğini belirlemek için, ters faz yüksek performans sıvı kromatografisi izokratik elüsyon metodu geliştirilmiştir.

Gereç ve Yöntemler: Kromatografik ayırım ve miktar tayini, C18 (ACE, $150 \mathrm{~mm} \times 4.6 \mathrm{~mm}, 5 \mu \mathrm{m}$ ) kolonda, asetonitril, $0.1 \mathrm{M}$ asetik asit (70: 30 , v/v) mobil fazı ile $1 \mathrm{~mL} / \mathrm{min}$ hızla, ultraviyole dedektörle $520 \mathrm{~nm}$ 'de gerçekleştirilmiștir.

Bulgular: Tüm analitlerde incelenen konsantrasyon aralığında (2-500 ppm) lineer davranış gözlenmiş, korelasyon katsayısı >0,998 olarak bulunmuştur. Önerilen yöntemin, Echium türlerindeki şikonin türevlerinin incelenmesi için spesifik ve kesin olduğu bulunmuştur.

Sonuç: Şikonin türevlerinin en yüksek içeriği E. italicum L.'de gözlemlenmiştir ve bu da E. italicum L. köklerinin şikonin türevleri için, alternatif bir kaynak olarak kullanılmasını desteklemektedir.

Anahtar kelimeler: Echium sp., şikonin türevleri, HPLC

\section{INTRODUCTION}

Species of Echium occur abundantly as a flowering plant native to North Africa, mainland Europe, and the Macaronesian islands, but have also become invasive in southern Africa and Australia.
Out of the 60 species of this genus, nine are found in Turkey: E. angustifolium, E. arenarium, E. italicum, E. glomeratum, E. oriantale, E. parviflorum, E. plantagineum, E. russicum, and E. vulgare. 
Based on the traditional documents on folk medicine, Echium sp. have been employed as diaphoretics, diuretics, expectorants, febrifuges, sedatives, analgesics, vulneraries, anxiolytics, and in the treatment of upper respiratory tract infections. ${ }^{1-4}$ Pharmacologic studies have demonstrated that species of Echium possess antioxidant ${ }^{5-7}$, anti-inflammatory ${ }^{8}$, antibacterial $^{9,10}$, antiviral ${ }^{11}$, antiproliferative ${ }^{12-14}$, analgesic ${ }^{15}$ and antidepressant ${ }^{16}$ activities. It is clinically proven as a useful and safe drug in patients with obsessive compulsive disorders. ${ }^{16-18}$ It is also reported that various extracts of $E$. amoenum have good antianxiety activity on in vivo models. ${ }^{19-23}$ Echium species contain a variety of phytochemicals, including naphthoquinones, flavonoids, pyrrolizidine alkaloids, steroids, anthocyanins, fatty acids, amino acids, and essential oils. Many shikonin (S) derivates (ShD) have been isolated from the roots of Echium plants. Naphthoquinones are a series of ShD such as $S$, acetylshikonin (AS), deoxyshikonin (DS), $\beta, \beta$-dimethylacrylshikonin (DMAS), isobutrylshikonin, isovalerylshikonin (IVS), and 2-methyl butrylshikonin (MBS). ${ }^{24}$

$\mathrm{S}, \mathrm{R}$ enantiomer of Alkannins, are lipophilic red pigments commonly known as isohexenylnaphthazarins. They are mostly found in more than 150 genus such as Lithospermum, Echium, Onosma, Anchusa, and Cynoglossum of the Boraginaceae family. Historically they were used as dyes by the ancient Greeks and Romans. S contains two parts structurally: the naphthazarine moiety (5, 8-dihydroxy-1, 4 naphthoquinone) and the chiral six-carbon side chain. It is readily sensitive to polymerization following treatment with acids, bases, heat, or light due to the naphthazarine core, and easily to oxidation by exposure to light or air just for the high chemical reactivity. Most of the ShD are present as ester derivatives linked with the hydroxyl group of the side chain, maintaining the naphthazarine moiety. ${ }^{25}$ ShD have attracted the attention of many researchers due to their several potential pharmacologic activities such as antimicrobial, antitumor, wound healing, and antioxidants. S extracts obtained from Lithospermum erythrorhizon induced apoptosis against human colorectal carcinoma cells, HL60 cells, and HeLa cells by the mechanism of tumor suppression via signaling pathways that possibly involved reactive oxygen species, p53, p27, Bcl-2, caspase, and inhibition of DNA topoisomerase I/II and telomerase. ${ }^{26-28}$ A clinical study showed that ShD were efficacious in the treatment of patients with late-stage lung cancer who were inappropriate for other treatment. ${ }^{29}$ Furthermore, the cream Helixderm ${ }^{\circledR}$, made from $\mathrm{S}$ and derivatives, has been evaluated for wound healing activity in clinical trials undertaken at the Freie University and showed good results with granulation and epithelization. ${ }^{30}$

In terms of the toxicologic effect of naphthoquinone compounds, it was reported that ShD did not induce any hematologic toxicity in animal models, which indicates that ShD may be safe for use in vivo ${ }^{31}$, whereas another report demonstrated toxicity in mice by intraperitoneal administration at a dose of $20 \mathrm{mg} / \mathrm{kg}$ for $\mathrm{S}$, $41.0 / 22.75 \mathrm{mg} / \mathrm{kg}$ for $\mathrm{AS}$, and $48 \mathrm{mg} / \mathrm{kg}$ for $3,3-\beta, \beta$-DMAS. In

addition, toxicity has also been observed during in vivo testing for the antitumor effects of ShD. ${ }^{32}$

Herbals and herbal drugs contain active ingredients present in the naturally occurring plant source in certain quantities, and the proportion between different constituents or active principles is a key quality parameter for the efficacy of the product. It is in this regard that the modern tools and techniques of analysis provide vital support and required evidence. According to our knowledge, there are no reports related to the phytochemical analyses of naphthoquinone derivatives in Echium sp. using high-performance liquid chromatography (HPLC) quantitatively. Thus, the aims of the present study were to quantify biologically active naphthoquinone derivatives in the ethanol extracts of the roots of four selected Echium species growing wild in Turkey.

\section{EXPERIMENTAL}

\section{HPLC analysis of shikonin derivatives in different samples}

\section{Plant material and chemicals}

E. italicum L., E. vulgare L., plant procured from $56 \mathrm{~km}$ north of Ankara, and E. angustifolium Miller., E. parviflorum Moench collected from the coast of Antalya province of Turkey, identified and authenticated by Dr. Gülderen Yılmaz, Assist. Professor, Ankara University, Faculty of Pharmacy, Department of Pharmaceutical Botany. A voucher specimen has been deposited in the Herbarium of Gazi University, Faculty of Pharmacy (GUE2991, GUE2992) and in the herbarium of Ankara University, Faculty of Pharmacy (AEF26023, AEF26024). The reference compounds were purchased from Pureone biotechnology Co. Ltd, China. Chemicals and reagents used in the study were of HPLC grade or analytical grade.

\section{Extraction of plant samples}

\section{Extraction of crude plant extracts}

The extraction procedure was performed as follows: the shadedried and coarsely powdered roots of four Echium sp. (100 g) were extracted with $96 \%$ alcohol $(2 \times 750 \mathrm{~mL})$ in a water bath with temperature of $40^{\circ} \mathrm{C}$ for $48 \mathrm{~h}$. After cooling, the material was filtered and the residue was further extracted with ethanol $(500 \mathrm{~mL}$ ) twice. Following this procedure, all the extracts were pooled together, concentrated under vacuum using a rotavapor (Büchi, Switzerland) to afford the alcoholic extract, and then freeze-dried (Figure 1).
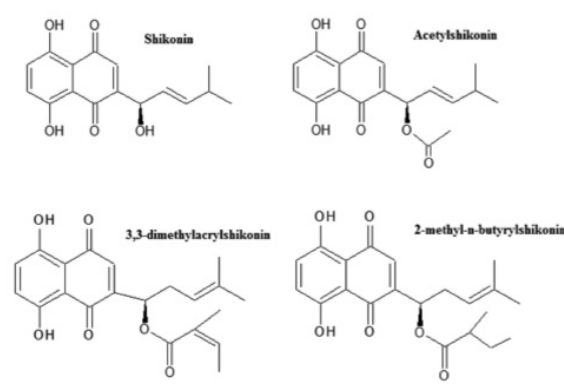

Figure 1. The structures of standard compounds
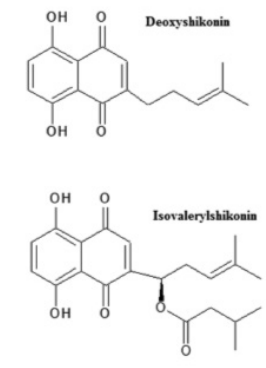
Identification of shikonin derivatives by thin-layer chromatography

Fifty milligrams of the ethanol extracts made from roots of four Echium species were taken into a set of $10 \mathrm{~mL}$ volumetric flasks separately and the volumes were completed to the mark with methanol. A $10-\mu \mathrm{L}$ aliquot of test samples of different extracts was applied to the TLC plate (aluminum foil-backed TLC plate coated with silica gel 60 F254, Merck, 0.2-mm layer thickness) separately. It was positioned $10 \mathrm{~mm}$ from the bottom of the plate, and then the plate was developed to a distance of about $9.5 \mathrm{~cm}$ using petroleum ether: ethyl acetate: acetic acid (85:15: $1 / v)$ as the mobile phase. The plates were then removed, airdried, and the spots were visualized under an ultraviolet (UV) lamp at $254 \mathrm{~nm}$ after spraying $5 \%$ sulfuric acid reagent on the plate and heated at $105^{\circ} \mathrm{C}$ for about 5 min until the bands are clearly visible. The chromatogram obtained with test solution showed a band corresponding to those of ShD (Figure 2).

\section{High-performance liquid chromatography}

\section{Instrumentation}

An Agilent 1200 LC system (equipped with a G1311A pump, G1328B manual injector, G1322A degasser, G1316A column heater, and G1314B variable wavelength UV-detector) was employed (Agilent Technologies-Santa Clara, CA).

\section{Chromatographic conditions}

An ACE 5 C18 (150 mm × $4.6 \mathrm{~mm}, 5 \mu \mathrm{m}$ ) (Scotland) reversedphase column was used as the stationary phase. An isocratic elution program was applied for chromatographic analysis. The mobile phase was a mixture of acetonitrile: $0.1 \mathrm{M}$ acetic acid contained water $=70: 30(\mathrm{pH}: 2.82)$ with isocratic elution, filtered through a $0.45-\mu \mathrm{m}$ membrane filter (Millipore) and degassed by sonication for $30 \mathrm{~min}$ prior to use. The analysis was performed at a flow-rate of $1.0 \mathrm{~mL} / \mathrm{min}$. The injection volume was adjusted to $10 \mu \mathrm{L}$. The temperature of the column was set to $25^{\circ} \mathrm{C}$. The analysis was performed at $520 \mathrm{~nm}$ because the maximum UV absorbance for the analytes were obtained at this wavelength.

\section{Preparation of test solution}

The dry extracted samples were weighed and finely powdered. Approximately $100 \mathrm{mg}$ of the ground powder was weighed carefully in the vials, then the sample was ultrasonically extracted with $15 \mathrm{~mL}$ methanol and $1 \mathrm{~mL}$ DMSO for about 30 $\mathrm{min}$. After cooling, the volume was made up to $50 \mathrm{~mL}$ with the same solvent. Prior to analysis, the extraction solutions were filtered through a $0.45-\mu \mathrm{m}$ filter membrane (Merck, Millipore) and $10-\mu \mathrm{L}$ aliquot was injected into the HPLC system.

\section{Preparation of standard solution}

A standard stock solution of S, AS, DS, DMAS, MBS, and IVS was prepared by dissolving $1.0 \mathrm{mg}$ of each compound in $10 \mathrm{~mL}$ of acetonitrile in a volumetric flask. For the determination of the limit of detection (LOD) and limit of quantification (LOQ), working standard solutions were prepared by further dilution of this stock solution with aqueous methanol.

\section{Calibration curve}

Linear calibration plots were obtained for the related standard compounds at six different concentration levels. After filtering through a $0.45-\mu \mathrm{m}$ membrane filter, $10 \mu \mathrm{L}$ of each concentration of the standard solution was injected into the HPLC system for analysis in triplicates. The regression equation and coefficient of correlation is given in Table 1 .

\section{Validation of method}

LOD and $L O Q$ were determined experimentally based on the signal-to-noise ratio until the average responses were approximately three $(\mathrm{S} / \mathrm{N}=3)$ and ten times $(\mathrm{S} / \mathrm{N}=10)$ that of the blank responses, respectively.

The accuracy of the method was ascertained by spiking the preanalyzed samples with a known amount of standard solution prepared at three concentration levels $(50,100$, and 150 ppm) in triplicate. The average percentage recovery was estimated by applying the values of the peak area to the regression equations of the calibration graph.

Precision test: The mixtures composed of S, DS, AS, DMAS, MBS, and IVS were taken and repeatedly injected six times to measure the peak areas respectively. The results are expressed as relative standard deviation (RSD).

The precision of the method (inter-day and intra-day variations of replicate determinations) was checked by injecting standard solution at different concentrations $(12.5,50$, and 100 ppm) in triplicate on the same day and on five consecutive days. The results are reported in terms of RSD.

\section{RESULTS AND DISCUSSION}

Identification of active compounds by thin-layer chromatography (TLC)

The structures of the reference compounds analyzed using TLC are shown in Figure 1. The separation of four Echium species

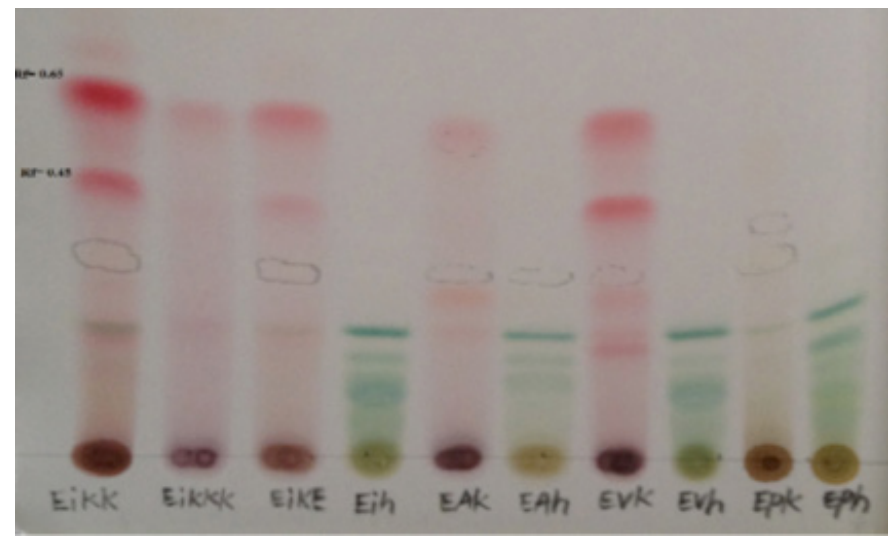

Figure 2. Thin layer chromatogram of four Echium species ethanol extracts from roots and aerial parts

EIKK: Chloroform extract of E. italicum roots, EIKKK: Chloroform extract of E. italicum root barks, EIKE: Ethanol extract of E. italicum roots, ElH: Ethanol extract of E. italicum aerial parts, EAK: Ethanol extract of E. angustifolium roots, EAH: Ethanol extract of E. angustifolium aerial parts, EVK: Ethanol extract of E. vulgare roots, EVH: Ethanol extract of E. vulgare aerial parts, EPK: Ethanol extract of E. parviflorum roots, and EPH: Ethanol extract of E. parviflorum aerial parts 
root and aerial part ethanol extract with TLC are presented in Figure 2. A comparative chromatographic assessment showed the presence of the ShD in alcoholic extracts of roots of E. italicum L. E. vulgare L. and E. angustifolium Miller. The identification of the bands of $\operatorname{ShD}\left(R_{f}=0.7 \sim 0.3\right)$ in the sample extract was confirmed by overlaying their absorption with those of the standard compounds at $254 \mathrm{~nm}$ and $366 \mathrm{~nm}$.

\section{Optimization of HPLC}

The critical aspects of developing a method in liquid chromatography are to provide good resolution between the studied compounds in the shortest analysis time. The current optimized conditions of HPLC with a C18 column and UV detector at $520 \mathrm{~nm}$ using isocratic mixture of acetonitrile and water as mobile phase achieved the best-resolved symmetric peaks for ShD. It was observed that the retention time of the reference standards was 4.176 16.58 $\mathrm{min}$ (Figure 3). The total run time of the ShD was found to be $20 \mathrm{~min}$ and the ShD in each extract could be observed on HPLC-UV chromatogram (Figure 4-7). This indicates that the present HPLC method is fast, specific, and convenient. The average retention time \pm SD for AS, S, DS, DMAS, MBS, and IVS was found to be $4.176 \pm 0.003$, $8.752 \pm 0.005,11.006 \pm 0.004,15.059 \pm 0.003,15.672 \pm 0.004$ and $16.584 \pm 0.003$, respectively, for six replicates.

\section{Validation of method}

Calibration graphs were generated by plotting the linear regression of the peak area versus the corresponding analyte concentration; the calibration curve for each analyte was obtained using six concentration in the range of 2-500 ppm. The linear correlation coefficient $\left(r^{2}\right)$ for all calibration curves was showing best linearity. The method was validated in terms of precision, accuracy, and other validation method parameters. The repeatability of the HPLC method and intermediate precisions for intra-day and inter-day variations are given in Table 1. The LOD value was found to be 0.19 2.01 ppm, which is the concentration that yields a signal-to-noise (S/N) ratio of 3:1. The $L O Q$ value under the described conditions was $0.57 \sim 6.03$ ppm with an S/N ratio of 10:1. This confirmed the sensitivity for the quantification of the compounds.

\section{HPLC analysis of shikonin derivatives in different samples}

The concentrations of the ShD in ethanol extracts of different

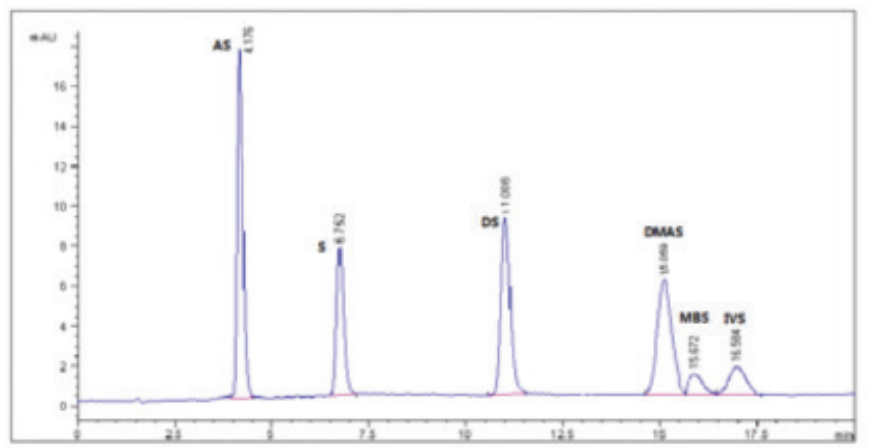

Figure 3. HPLC-UV chromatogram of reference standard mixtures prepared of $50 \mathrm{ppm}$

HPLC-UV: High-performance liquid chromatography-ultraviolet, AS: Acetylshikonin, S: Shikonin, DS: Deoxyshikonin, DMAS: $\beta, \quad \beta$-dimethylacryshikonin, IVS: Isovalerylshikonin, MBS: 2-methyl butrylshikonin

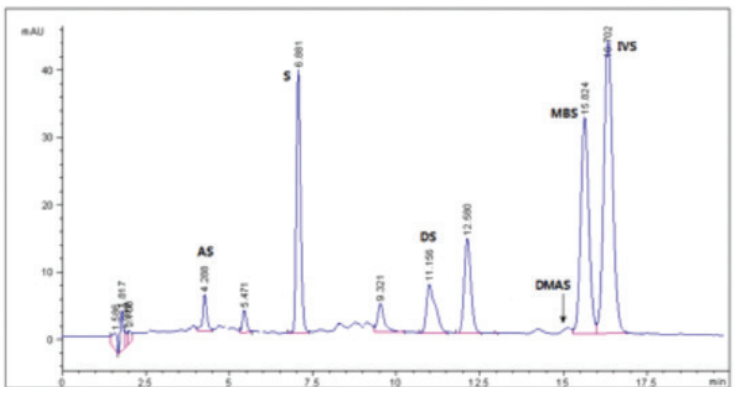

Figure 4. HPLC-UV chromatogram of ethanol extract of E. italicum L. root HPLC-UV: High-performance liquid chromatography-ultraviolet, AS: Acetylshikonin, S: Shikonin, DS: Deoxyshikonin, DMAS: $\beta, \quad \beta$-dimethylacryshikoninç IVS: Isovalerylshikonin, MBS: 2-methyl butrylshikonin

\section{Table 1. Validation parameters of the HPLC method for the determination of shikonin derivatives}

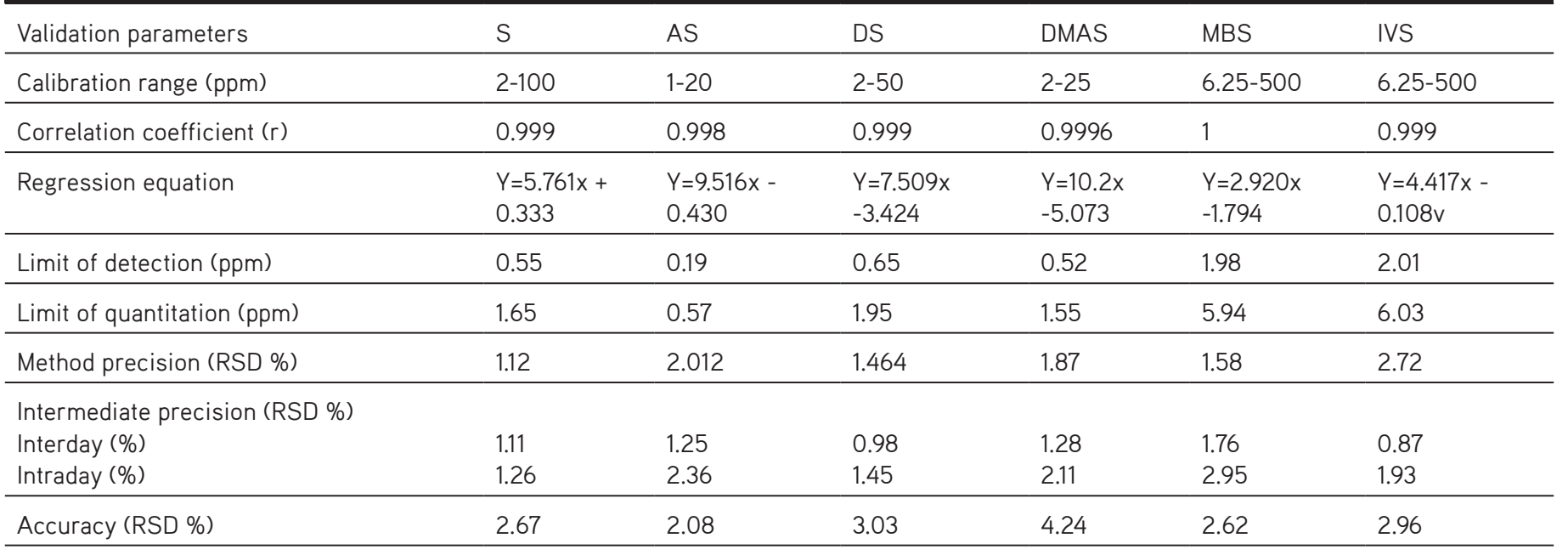

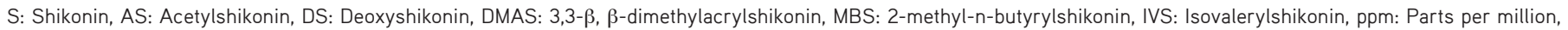
RSD: Relative standard deviation 


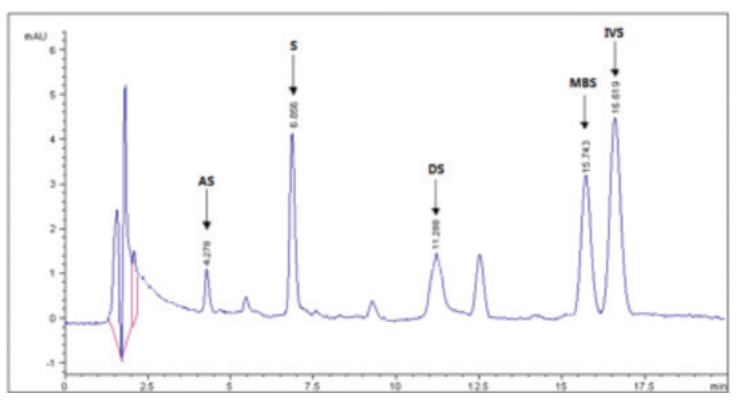

Figure 5. HPLC-UV chromatogram of ethanol extract of $E$. vulgare L. root HPLC-UV: High-performance liquid chromatography-ultraviolet, AS: Acetylshikonin, S: Shikonin, DS: Deoxyshikonin, DMAS: $\beta, \quad \beta$-dimethylacryshikonin, IVS: Isovalerylshikonin, MBS: 2-methyl butrylshikonin

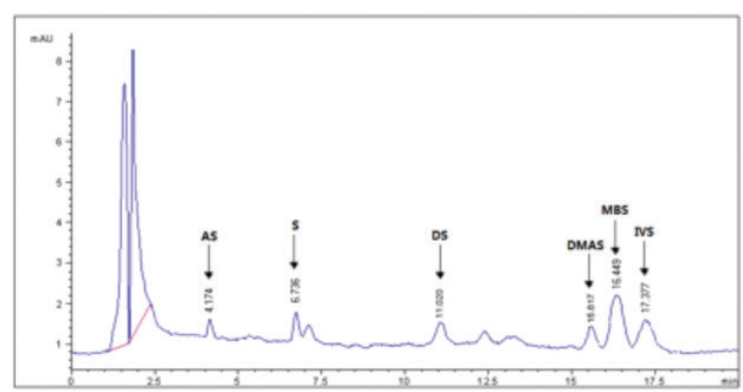

Figure 6. HPLC-UV chromatogram of ethanol extract of $E$. angustifolium Miller root

HPLC-UV: High-performance liquid chromatography-ultraviolet, AS: Acetylshikonin, S: Shikonin, DS: Deoxyshikonin, DMAS: $\beta, \quad \beta$-dimethylacryshikonin, IVS: Isovalerylshikonin, MBS: 2-methyl butrylshikonin

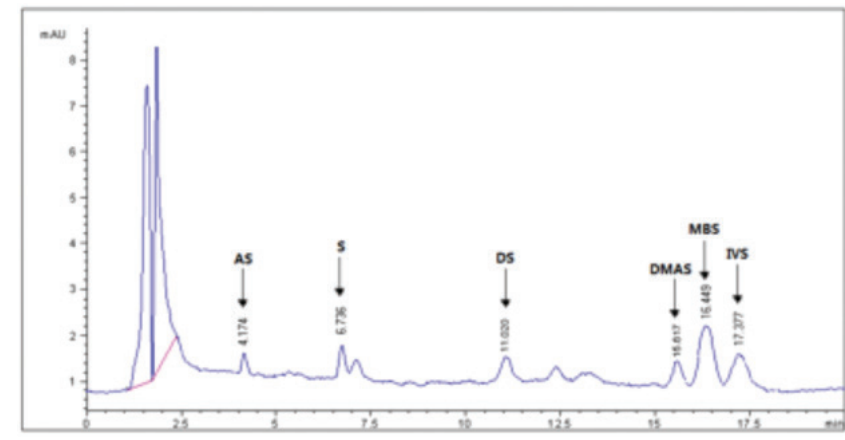

Figure 7. HPLC-UV chromatogram of ethanol extract of E. parviflorum Moench root

HPLC-UV: High-performance liquid chromatography-ultraviolet, AS: Acetylshikonin, S: Shikonin, DS: Deoxyshikonin, DMAS: $\beta, \quad \beta$-dimethylacryshikonin, IVS: Isovalerylshikonin, MBS: 2-methyl butrylshikonin
Echium species were determined from the peak-area ratios using the equations of linear regression obtained from the calibration curves. Data for the concentration of ShD in ethanol extracts obtained from different Echium species growing wild in Turkey are presented in Table 2. As can be observed, the content of ShD was the highest in E. italicum L. compared with the other species.

\section{CONCLUSIONS}

$S$ and derivatives are naturally occurring isohexenylnaphthazarine compounds, which are used as a red dye in drugs, cosmetics, and the textile industry in the Far East and Europe ${ }^{33}$, and comprise the active ingredients of several pharmaceutical preparations because they exert potent biologic activities with wound healing, antimicrobial, cytotoxic, and antioxidant properties. However, these bioactive constituents become expensive due to their physical instability and tedious separation process. Therefore, it is important to develop a simple, fast, and sensitive method to evaluate $S$ compounds in drugs, extracts, and pharmaceutical preparations. The implications of the current study are important because we have standardized the raw materials and preparations of the studied four Echium sp. roots for the first time. To the best of our knowledge, this is the first study to determine the amount of $S$ and $S h D$ in the four Echium sp. We developed a simple, accurate, fast, and reproducible HPLC method to quantify the active principles in Echium species. This method can be used for routine quality control analysis of this species. Although ShD are the main constituents of Echium sp. roots, the results of the current study also indicate that the maximum $\mathrm{S}$ derivative content in Echium species can be found in Echium italicum L. extract as compared with other studied extracts. Since most of the biologic activities such as antimicrobial, antiproliferative, antioxidant, analgesic, and antidepressant activities of Echium sp. roots can be attributed to $\mathrm{ShD}$, the quantification of such compounds in the roots of these plants need to be considered as very important for the future use of preparations of these plants in several areas of clinical medicine. By using the optimized separation method described above, ShD can be detected in herbals or formulations prepared from Boraginaceae family plants, which are rich in naphthoquinone derivatives. We have demonstrated that the method is suitable for application in quality control of herbal formulations.

\section{ACKNOWLEDGEMENT}

The authors thank Osman Üstün, Uğur Tamer and Murat Şüküroğlu for helping with the research. The author would like

Table 2. Quantitative determination of shikonin derivatives in each Echium species

\begin{tabular}{|c|c|c|c|c|c|c|}
\hline Content (w/w \%) & 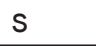 & AS & DS & DMAS & MBS & IVS \\
\hline E. italicum L. root alcoholic extract & 0.391 & 0.037 & 0.105 & 0.015 & 1.147 & 1.185 \\
\hline E. vulgare L. root alcoholic extract & 0.053 & 0.040 & 0.022 & 0.004 & 0.162 & 0.121 \\
\hline E. angustifolium Millter root alcoholic extract & 0.007 & 0.003 & 0.009 & 0.010 & 0.074 & 0.028 \\
\hline E. parviflorum Moench root alcoholic extract & 0.007 & 0.003 & 0.008 & n.d. ${ }^{*}$ & 0.023 & 0.015 \\
\hline
\end{tabular}

*n.d.: Not detected, w/w: Weight by weight, AS: Acetylshikonin, DS: Deoxyshikonin, DMAS: 3,3- $\beta, \beta$-dimethylacrylshikonin 
to thank Ali Çetin for his careful reading of the manuscript and helpful comments and suggestions. This work was supported by the Gazi University Academic Research Grants [grant number: GÜBAP 02-2010/2011].

Conflict of Interest: No conflict of interest was declared by the author.

\section{REFERENCES}

1. Ahvazi M, Khalighi-Sigaroodi F, Charkhchiyan MM, Mojab F, Mozaffarian VA, Zakeri $\mathrm{H}$. Introduction of medicinal plants species with the most traditional usage in Alamut region. Iran J Pharm Res. 2012;11:185-194.

2. Çakilcioğlu U, Turkoglu I. An ethnobotanical survey of medicinal plants in Sivrice (Elazığ-Turkey). J Ethnopharmacol. 2010;132:165-175.

3. Chevallier A. The Encyclopedia of Medicinal Plants. Dorling Kindersley Limited, London; 1996.

4. Grieve M. A Modern Herbal 2. Dover Publications. NewYork; 1982.

5. Ferreira ICFR, Aires E, Barreira JCM, Estevinho LM. Antioxidant activity of Portuguese honey samples: Different contributions of the entire honey and phenolic extract. Food Chemistry. 2009;114:1438-1443.

6. Niciforovic N, Mihailovic V, Maskovic P, Solujic S, Stojkovic a, Pavlovic Muratspahic D. Antioxidant activity of selected plant species; potential new sources of natural antioxidants. Food Chem Toxicol. 2010;48:31253130.

7. Ranjbar A, Khorami S, Safarabadi M, Shahmoradi A, Malekirad AA, Vakilian K, Mandegary A, Abdollahi M. Antioxidant Activity of Iranian Echium amoenum Fisch \& C.A. Mey Flower Decoction in Humans: A cross-sectional Before/After Clinical Trial. Evid Based Complement Alternat Med. 2006;3:469-473.

8. Abed A, Minaiyan M, Ghannadi A, Mahzouni P, Babavalian MR. Effect of Echium amoenum Fisch. et Mey a Traditional Iranian Herbal Remedy in an Experimental Model of Acute Pancreatitis. ISRN Gastroenterol. 2012;2012:141548.

9. Abolhassani M. Antibacterial Effect of Borage (Echium amoenum) on Staphylococcus aureus. Braz J Infect Dis. 2004;8:382-385.

10. Karakaş FP, Yildirim A, Türker A. Biological screening of various medicinal plant extracts for antibacterial and antitumor activities. Turk J Biol. 2012;36:641-652.

11. Farahani M. Antiviral Effect Assay of Aqueous Extract of Echium amoenum-L against HSV-1. Zahedan J Res Med Sci. 2013;15:46-48.

12. Conforti F, loele G, Statti GA, Marrelli M, Ragno G, Menichini F. Antiproliferative activity against human tumor cell lines and toxicity test on Mediterranean dietary plants. Food Chem Toxicol. 2008;46:33253332.

13. Uysal $H$, Kizilet $H$, Ayar A, Taheri A. The use of endemic Iranian plant, Echium amoenum, against the ethyl methanesulfonate and the recovery of mutagenic effects. Toxicol Ind Health. 2015;31:44-51.

14. Wassel G, el-Menshawi B, Saeed A, Mahran G, el-Merzabani M. Screening of selected plants for pyrrolizidine alkaloids and antitumor activity. Pharmazie. 1987;42:709.

15. Heidari MR, Azad EM, Mehrabani M. Evaluation of the analgesic effect of Echium amoenum Fisch \& C.A. Mey. extract in mice: possible mechanism involved. J Ethnopharmacol. 2006;103:345-349.

16. Moallem SA, Hosseinzadeh H, Ghoncheh F. Evaluation of Antidepressant
Effects of Aerial Parts of Echium vulgare on Mice. JBMS. 2007;10:189-196.

17. Sayyah M, Kamalinejad M. A preliminary randomized double blind clinical trial on the efficacy of aqueous extract of Echium amoenum in the treatment of mild to moderate major depression. Prog Neuropsychopharmacol Biol Psychiatry. 2006;30:166-169.

18. Sayyah M, Boostani H, Pakseresht S, Malaieri A. Efficacy of aqueous extract of Echium amoenum in treatment of obsessive-compulsive disorder. Prog Neuropsychopharmacol Biol Psychiatry. 2009;33:15131516.

19. Gholamzadeh S, Zare S, Ilkhanipoor M. Evaluation of the anxiolytic effect of Echium amoenum petals extract, during chronic treatment in rat. Research in pharmaceutical science. 2007;2:91-95.

20. Gholamzadeh S, Zare S, Ilkhanipoor M. Anxiolytic Effect of Echium amoenum During Different Treatment Courses. Research Journal of Biological Sciences. 2008;3:176-178.

21. Gomes NG, Campos MG, Orfao JM, Ribeiro CA. Plants with neurobiological activity as potential targets for drug discovery. Prog Neuropsychopharmacol Biol Psychiatry. 2009;33:1372-1389.

22. Rabbani M, Sajjadi SE, Vaseghi G, Jafarian A. Anxiolytic effects of Echium amoenum on the elevated plus-maze model of anxiety in mice. Fitoterapia. 2004;75:457-464.

23. Shafaghi B, Naderi N, Tahmasb L, Kamalinejad M. Anxiolytic Effect of Echium amoenum L. in Mice. Iranian Journal of Pharmaceutical Research. 2002;1:37-41.

24. Albreht A, Vovk I, Simonovska B, Srbinoska M. Identification of shikonin and its ester derivatives from the roots of Echium italicum L. J Chromatogr A. 2009;1216:3156-3162.

25. Wang R, Yin R, Zhou W, Xu DF, Li S. Shikonin and its derivatives: a patent review. Expert Opin Ther Pat. 2012;22:977-997.

26. Hsu PC, Huang YT, Tsai ML, Wang YJ, Lin JK, Pan MH. Induction of apoptosis by shikonin through coordi native modulation of the $\mathrm{Bcl}-2$ family, p27, and p53, release of cytochrome c, and sequential activation of caspases in human colorectal carcinoma cells. J Agric Food Chem. 2004;52:6330-6337.

27. Gao D, Hiromura M, Yasui $H$, Sakurai $H$. Direct reaction between shikonin and thiols induces apoptosis in HL60 cells. Biol Pharm Bull. 2002;25:827-832.

28. Wu Z, Wu LJ, Li LH, Tashiro S, Onodera S, Ikejima T. Shikonin regulates HeLa cell death via caspase- 3 activation and blockage of DNA synthesis. J Asian Nat Prod Res. 2004;6:155-166.

29. Guo XP, Zhang XY, Zhang SD. Clinical trial on the effects of shikonin mixture on later stage lung cancer. Zhong Xi Yi Jie He Za Zhi. 1991;11:598-599.

30. Papageorgiou VP, Assimopoulou AN, Ballis AC. Alkannins and Shikonins: A New Class of Wound Healing Agents. Curr Med Chem. 2008;15:3248-3267.

31. Su L, Liu LH, Wang Y, Yan G, Zhang Y. Long term systemic toxicity of shikonin derivatives in Wistar rats. Pharm Biol. 2014;52:486-490.

32. Papageorgiou VP, Assimopoulou AN, Couldouros EA, Heapworth D, Nicoloau KC. The Chemistry and Biology of Alkannin, Shikonin, and Related Naphthazarin Natural Products. Angew Chem Int Ed. 1999;38:270-300.

33. Bozan B, Baser KHC, Kara S. Quantitative determination of naphthoquinones of Arnebia densiflora by TLC-densitometry. Fitoterapia. 1999;70:402-406 